\author{
Akito Okada \\ Tokyo University of Foreign Studies, Professor, Phd Doctor, Japan, Tokyo, \\ e-mail: aokada@tufs.ac.jp
}

\title{
EDUCATION POLICY AND THE JAPANESE NEW KNOWLEDGE SOCIETY
}

Improving educational institution has been shown to advance socioeconomic development, reduce inequality, enhance the economic competitiveness of nations, and fortify governmental institutions. Nevertheless, the Japanese school system faces many obstacles in getting meaningful education reforms approved or implemented.

Firstly, this article analyses education policy and reform in Japan over the past 20 years, especially focusing on revising the Course of Study (Gakushū Shidō Yōryō) towards 2020, during the rapid emergence of a "new knowledge society". Secondly, it is to sort out how the issue of "equal educational opportunities" has been discussed while going through the education reform in recent years. The rarity of educational opportunity in Japan is more evident in the limitation of access to high-quality primary and secondary education to children whose households are affluent enough to afford accommodation in at least middle-class neighborhoods, or to those who can afford private schools. Since education is an important role of any government, and because the government is the predominant provider of this opportunity to the masses, appropriately distinct restrictions on its dissemination and delivery must and do exist.

Key words: education policy in Japan, "new knowledge society", "equal educational opportunities", Japanese school system.

\section{Акито Окада \\ PhD докторы, профессор, Токио шет тілдер университеті, Жапония, Токио қ., e-mail: aokada@tufs.ac.jp}

\section{Бікім беру саясаты және жапондық жаңа бікім қоғамы}

Білім беру мекемелерін жетілдіру әлеуметтік-экономикалық, дамуға, теңсіздікті төмендетуге, халықтардың экономикалық бәсекеге қабілеттілігін арттыруға және мемлекеттік институттарды нығайтуға ықпал етеді. Аегенмен, жапондық мектеп жүйесі мақұлданған немесе енгізілген білім беру ресрормаларын жүзеге асыруда көптеген кедергілерге тап болып жатыр.

Осы мақалада Жапонияда соңғы 20 жылдың ішінде жүргізілген білім беру саясатын және реформаларды, атап айтқанда 2020 жылы «жаңа білім қоғамы» (Gakushū Shidō Yōryō) пайда болатын кезге сәйкес оқу курсының қайта қаралуы сараланады. Сонымен қатар соңғы жылдары білім беру реформасын жүзеге асыру барысындағы «білім берудің тең мүмкіндіктері» мәселесі талқыланады. Жапонияда білім алудың қиындығы - балаларын жекеменшік мектептерге беруге мүмкіндігі бар немесе орта класс өкілдері шоғырланған ауданнан пәтер алуға жағдайы жетерлік жоғары табысты жанұядан шыққан оқушылардың, ең болмағанда сапалы бастауыш және орта білім алу мүмкіндігінің шектеулігінен анық байқалады. Білім беру - кез келген мемлекеттің маңызды атқаратын қызметі және үкімет жалпы халық үшін осы мүмкіндікті негізгі жеткізуші болғандықтан, оны тарату мен қамтамасыз етуде нақты шектеулер болуы керек.

Түйін сөздер: Жапониядағы білім беру саясаты, «жаңа білім қоғамы», «білім берудің тең мүмкіндіктері», жапондық мектеп жүйесі. 


\title{
Акито ОкаАа \\ Phd доктор, профессор, Токийский университет иностранных языков, Япония, г. Токио, e-mail: aokada@tufs.ac.jp \\ Политика образования и японское общество новых знаний
}

\begin{abstract}
Улучшение образовательных учреждений способствует социально-экономическому развитию, сокращению неравенства, повышению экономической конкурентоспособности наций и укреплению государственных учреждений. Тем не менее, японская школьная система сталкивается со многими препятствиями в получении одобренных или реализованных значимых образовательных реформ.

В этой статье анализируются политика и реформы в области образования Японии за последние 20 лет, в частности, основное внимание уделяется пересмотру учебного курса (Gakushü Shidō Yōryō) к 2020 году в период появления «общества новых знаний». Анализируется, каким образом решается проблема «равных образовательных возможностей» при проведении реформы образования в последние годы. Сложность получения образования в Японии ярко выражена в ограничении доступа к высококачественному начальному и среднему образованию Аля детей, чьи семьи недостаточно состоятельны, чтобы позволить себе жилье, по крайней мере, в районах среднего класса, или для тех, кто не может позволить себе частные школы. Поскольку образование является важным Аля Аюбого правительства и поскольку правительство может преАоставить эту возможность широким массам, то должны существовать четкие ограничения на его распространение и предоставление.
\end{abstract}

Ключевые слова: образовательная политика Японии, «общество новых знаний», «равные образовательные возможности», японская школьная система.

\section{Introduction}

Improving educational institution has been shown to advance socioeconomic development, reduce inequality, enhance the economic competitiveness of nations, and fortify governmental institutions. Nevertheless, the Japanese school system faces many obstacles in getting meaningful education reforms approved or implemented.

Recently, the central government of Japan has proposed a new educational system different from that of the past. The Ministry of Education, Culture, Sports, Science and Technology (MEXT) will revise the Course of Study by 2020 for all schools, from kindergarten through higher education, and reorganize their programs in order to ensure a fixed standard of education throughout the country.

MEXT has two aspirations for the new national education system. First, it should directly serve the needs of the rapid economic development taking place in the world. Second, it should include "equal opportunities" for education, as proposed by the Liberal Democratic Party. Based on these two ideas, they will reorganize the national education system according to the educational model of "active learning."

Firstly, this article analyses education policy and reform in Japan over the past 20 years, especially focusing on revising the Course of Study (Gakush $\bar{u}$ Shido Yōryō) towards 2020, during the rapid emergence of a "new knowledge society". Secondly, it is to sort out how the issue of "equal educational opportunities" has been discussed while going through the education reform in recent years.

\section{What is a new knowledge society?}

There is a world-wide view among policy makers, entrepreneurs, and researchers that knowledge is becoming an increasingly significant driving force for national prosperity and profitability (Stehr, N., 1994, Powell and Snellman, 2004). A 'new knowledge society' upholds what needs to be done to suit the use of data, information, and knowledge. As for the new knowledge society, while there is general consent on the appropriateness of the expression, the same cannot be said of the content. About which types of knowledge are we talking? At present, there is no generally accepted view as to what constitutes the knowledge society, and there is uncertainty as to how living conditions, working conditions, and industrial relations relate to each other in that society.

Social order profoundly depends upon data and elucidation refinement. At the core of social order, the knowledge society of the late twentieth and early twenty-first centuries represents the convergence of various analogous intellectual movements, creating five areas for primary consideration are (UNESCO, 2005): the evolution of knowledge societies, founded on substantial 
dissemination and subsequent employment of information and communication technologies (ICT); the broadening influence of organizational and technological modernization stimulating private enterprise by expanding performance and efficacy; the evolution of service economies: where the service sector monopolizes economies, in which service is the foundation of administration, and specialized amenities afford significant instruction to organizations; the attempts to forge scholarly institutions and establish knowledge oversight, increasing data resource efficiency, data capital, and proficiency; and key advances related to the above, including globalization, demographic frameworks and cultural conventions, and environmental interests.

Such evolutions have ramifications on living and working environments in addition to the more obvious effects on Japan's industrial relations. The manners in which they are not only mutually shaping, but also being shaped by the myriad government policies and strategies are still emerging and maturing. However, little effort has been spent on consolidating knowledge from these expansive and far-reaching issues. Therefore, the exact anatomy and extent of the consequences is as yet ambiguous.

\section{Education reform in Japan's new knowledge society}

The idea of the 'new knowledge society' has become a key and contested term in debates about educational reform in Japan. It is disputed whether the increased complexity, diversity, and insecurity brought about by the amplified flow of people and information in a globalizing world raise significant and specific issues for education. From about ten years before to ten years after the new century, policy makers together with the Ministry of Education, Culture, Sports, Science, and Technology (MEXT) have made several attempts to introduce changes to school curriculums from compulsory education to the higher education level.

At present, the framework conditions that challenge the sustainable development of the education system in new knowledge societies are shaped by the increasing 'VUCA' concept (Mack, O., Khare, A., Krämer, A., \& Burgartz, T., 2015). VUCA is an acronym that stands for volatility, uncertainty, complexity, and ambiguity, a combination of qualities that, taken together, characterize the nature of some difficult conditions and situations. The term VUCA originated with the United States Army War College to describe conditions resulting from the Cold War and has been adopted throughout businesses and organizations in many industries and sectors to guide leadership and strategy planning. Volatility refers to experiencing the uncertainty of frequent and radical accelerated fluctuations, for example the rapid rise and fall of prices in volatile markets where trends abruptly reverse and result in unpredictability. Ambiguity materializes through the lack of decipherability, which escalates the challenges of precisely comprehending a given situation. Complexity manifests itself in a rhizome of issues and factors, many of which are labyrinthinely interrelated. Since its first appearance in the 1990s, the concept was quickly embraced by other fields such as education to foster new abilities and talents, for example, strategic decision-making, risk management, and situational problem solving (Petrie, N. 2014).

Against this backdrop, the Japanese government, over the past couple of decades, has been directing panels of education experts to consider reforms that would help Japanese students prepare for the new knowledge society (DeCoker, G. \& Bjork, C., 2013). For them, new knowledge society means that reforms are needed to compete and succeed in the changing economic and political dynamics of the modern world. It also refers to societies that are well educated, and who therefore rely on the knowledge of their citizens to drive the innovation, entrepreneurship, and dynamism of that society's economy (MEXT, 2013a).

Since the late 1980s, Japanese society has undergone great transformations. The Cold War structures between East and West crumbled, and socioeconomic globalization advanced, but on the other hand, school violence, bullying, school absenteeism, and the phenomenon of "class disruption" became evident in schools, and juvenile crime and child abuse turned into social problems. With the imminent arrival of the 21st century, the Central Council for Education (Chūō kyōiku shingikai, CCE) started to study future models for education based on the prospects for the new knowledge society.

After the findings of 1995, the CCE took two years and contemplated and discussed. During that time, they compiled two reports on The Model for Japanese Education in the Perspective of the 21st Century. These two reports offered a spectrum of recommendations founded on nurturing a "zest for life (ikiruchikawa)" in students, especially in children, and the essentiality of focusing on an education that paired the competencies and the personality of the individual student in order to fully facilitate the actualization of their self-fulfillment in addition to a richness of spirit. According to the reports, "zest 
for life" is composed of: "abilities/capacities to enable children to identify tasks, to learn and think on their own, to make judgments proactively, and to act for making better solutions"; "a rich personality to discipline oneself, to collaborate with others, to care for others and to get emotional sensations"; and "health and physical strength for living". At the time, a number of leaders in different sectors of Japan expressed concern that Japanese schools produced graduates that had strong basic academic skills, but lacked creativity, independence, and the desire to be lifelong learners (Cave, P., 2007). Japan had seen switches in emphasis as educators sought to move beyond a traditional system based on rotelearning in order to help students learn to think for themselves. $\square$

In the CCE's first report compiled in 1996, the CCE recommended giving priority to nurturing "zest for life" in "yutori kyoiku" which was interpreted as more relaxed education or education with some freedom. By extention, the report also suggested reducing the yearly total of teaching hours by the number of hours previously allocated to Saturday studies in order to harmonize the system with the complete establishment of the five-day school week system (which meant a 30\% cut in the school curriculum) and underscore that the contents of education needs careful selection to actualize this objective. In parallel, the concept of "integrated learning" (sogo teki na gakushu no jikan) was introduced, giving schools and teachers greater freedom in selecting topics and areas of study. By drawing links between different topics, phenomena, and outcomes, the intention was to strengthen student competency and cultivate creative thinking.

Once again, the objectives of Japanese education have recently altered to acknowledge the recognized and anticipated necessities of the rapidly-transforming knowledge society, so that Japanese children can persevere in present and future global economic competition. Since 2004, the Japanese education system has been altered through a succession of PISA results and public reaction to earlier reforms to ensure pupils receive a robust knowledge foundation, making the nation consistently attain high PISA scores. Yet, the PISA 2003 reading test began emphasizing resolving questions in differing circumstances over the arguably more straightforward reproduction of content, and scores fell from 522 to 498 points. This dramatic drop resulted in a 'PISA shock' that inturn resulted in a national deliberation on education policy. Public concerns were later confirmed in
2006 when the PISA scores displayed only meager student ambitions toward the sciences.

\section{Recent revision of the course of study}

Since the middle of the 1990s, two movements have monopolized Japan's domestic debate concerning education. These trends embodied the discord existing between the catch phrase 'yutori kyoiku' to foster 'zest for life' and the development of academic competence, which was a targeted reaction to the decline in academic achievement (specifically in math, science, and literacy competency) compared to students of similar levels in other industrialized nations. In response to pressures from parents, the Japanese government implemented a new plan for the Course of Study (Gakushū Shidō Yōryō: COS) in 2011, representing an attempt to maintain some of the benefits of the educational reforms of the 1990s and the 2000s while increasing the academic rigor of Japanese compulsory education. Beginning with the 2011 revision, COS focused on the establishment of a substantial and strong knowledge base that balanced and reinforced 'creative' and 'critical' thinking. As a consequence, lesson times were extended by one to two hours per week in primary and lower secondary schools, and elementary school textbooks were expanded by almost $25 \%$ in an effort to accomodate the newly lengthened curriculum. Simultaneously, 'PISA-type' open-constructed tasks began being introduced into Japan's national assessments in an endeavor to validate the importance of skills considered integral for the new knowledge society. In making these alterations, education policy makers held that they were attempting to meld the finest qualities of both Japanese tradition with innovation to better prepare students the nation's future knowledge society.

At this point, brief clarification concerning the COS is warranted. Contingent on the School Education Act, MEXT circumscribes and regulates the standards for Japanese schools to codify their curriculums and thereby establish commensurate education standards known as the COS for all of Japan. The COS designates scopic standards for objectives and the content of each subject at elementary schools, lower secondary schools, and upper secondary schools. Moreover, the Ordinance for Enforcement of the School Education Act also establishes the standard number of annual class hours for elementary and lower secondary schools. Within this framework, each school develops a curriculum interrelated to local circumstances while cognitive of the relevant COS and the standards such as annual class hours imposed by the Ordinance. Although the 
initial COS were created on the heels of World War II as trials, they have customarily been amended relative to fluctuating societal requirements every 10 years since 1958 .

Targeting the 2020 Tokyo Olympics, the plan of the new COS through elementary education to upper secondary school was formally released in 2014 . The government and MEXT decided to use their next regular revision of the COS to roll back some innovations and extend the curriculum and classtime, while emphasizing the long-term importance of the zest for living strategy.

Yet, the policy makers became aware of the shortage of a good model of abilities for future Japanese children. As mentioned above, the PISA shock gave an impetus to the Japanese to begin to speculate on what kind of learning would contribute to the development children's logical thinking abilities. Therefore, the plan proposed the new direction of ability for the 21 st century in Japan. The model now is to build 'solid academic basics and key competency' by

- escaping from a binary opposition-like argument "yutori kyōiku," or "cram education";

- reconsidering core subjects (introducing English-language teaching to students at the thirdgrade level);

- introducing "Active learning" for fostering new nature and the ability of students (MEXT, 2013b)

As icons of the newly refined orientation for the $21^{\text {st }}$ century's plan, three critical terms were identified (competency, a new core subject curriculum, and active learning) for developing the abilities of future Japanese children. The plan went on to further state that students, children in particular, required the cognitive capacities to assess reading content critically and to express ideas both coherently and precisely in written and spoken contexts. Moreover, they needed to comprehend scientific and mathematical rational with a sufficient degree of competence. It was essential for these students to further their overall understanding of integrated and applicable knowledge, instead of decontextualized and compartmentalized assemblages of varied facts. In addition, they required the specific ability to assume individual responsibility for pursuing life-long learning. Because of these three perceived needs, the Japanese government began their sweeping reorganization of the nation's education system.

This modern terminology, recent to the general populous, has motivated them to create a plan of action for increasing new ability, which sounds promising as a guarantee for future prospects of national educational reform. Yet, there remains an underlying obstacle inherent in the proposed plan's averred pivotal wording; it does not identify the manner of ability the key competency signify, state what ability the redesigned curriculum cultivates, or even identify what ability the active learning builds, meaning the plan culminated with a title abundant with keywords, yet lacking in any meaningful or substantial examples of the ability it is intended to foster. One reason for the inability to produce or even engineer explicit examples is that concrete depictions of knowledge of the logical thinking are challenging. A second reason is that they are unfamiliar with contemplating concrete images embodying the essence of critical thinking. In fact, the government and MEXT undeniably do not entirely realize what they declare about the key competency unless they are able to visualize concrete examples of their alleged goals.

Considering equity in recent education reform by the Liberal Democratic Party

Against this backdrop, other issues also arise when we try to interpret equality of educational opportunity. This section is to show how the issue of "equal educational opportunities" has been discussed while going through the education policy and the education reforms in Japan for 2020. It discusses current issues, how the study of education can approach these issues, and indicates a focused method on the perspectives of equal opportunity.

Japan underwent rapid economic growth after the Second World War. However, since the 1990s, the country confronted a long recession and the increase in socio-economic inequality. Since the late 1990s, Japan also faced a radical neoliberal reforming of its social systems due to changes in its conservative political leadership by the Liberal Democratic Party (Jiyū minshutō, LDP). Amid such transformation, Japan saw a rise in its unemployment rate. Moreover, a rising Gini coefficient over the period pointed out growing income inequality (Chiavacci, D. \& Hommerich, C., 2017).

These socio-economic changes developed simultaneous changes in educational policy over time. The Japanese education system was once known for its egalitarianism that provided equal opportunities for all children (Cummings 1982, Okada 2011). However, neoliberal and marketoriented educational reform by the LDP since the late 1990s implemented school choice, ability grouping, 
and accountability in the state school system, which seemed to have caused the breakdown of postwar egalitarian characteristics in Japanese education.

\section{Major issues of educational equity in Japan}

Since the 1980s, with the rationale of neoliberal education ardently advocating ameliorating or moderating laws, procedures, and parental options, while bolstering rivalry, development, and growth among scholastic institutions, discrepancy in the debate regarding equal educational opportunity has evolved and become increasingly significant (Fujita 1997). By overlooking the disparity among scholastic institutions and introducing freedom of choice, the divide between varied scholastic institutions will unavoidably broaden, inflaming greater competition in entrance examinations. In such contexts, school choice freedom might become an entitlement or privilege accessible only to the moneyed classes, and in some manner, further engendering the broadening of entrance examination markets enveloping both public and private scholastic institutions (Kawaguchi, 2013).

Educational sociologists equated the education system of Japan from the late 1990s and 2000s to "the collapse of the national educational system," and recorded an expanding socioeconomic divide among students' academic achievements and learning motivations. These two points, established by their previous studies, encapsulate the most current and essential assertions for amendments to Japan's education system.

Under such circumstances, the question arises as to what outcome will result from these socioeconomic and educational changes with respect to social stratification and educational inequality.

There have been an increasing number of education sociology studies that revealed the relationship between family background and academic achievement.

For instance, Kariya and his colleagues (2001) correlated scholastic performance statistics in Japan's Western precincts and revealed that elementary and middle school students' academic performance had deteriorated significantly while also broadening its divide from 1989 to 2001. Kariya and his colleagues successfully demonstrated that household environment and independent ancillary instruction were potential determinants for this performance disparity. He also proposed that national curriculum standard alterations moving toward yutori since 1998 induced affluent households to turn to independent ancillary tutoring, which in turn worked to expand the socioeconomic divide in scholastic performance even further.

From 2007 to 2008, Mimizuka and his colleagues (2008) assembled and examined statistics regarding the students, parents, and school principals of three major areas in Japan (metropolitan, suburban, and rural). With Japan's Ministry of Education financing, Mikizuka's investigation searched for evidence indicating impacts on students' scholastic performance from parental education, occupation, family revenue, and any ancillary instruction disbursements. Results of Mikizuka's study strikingly indicated a significant socioeconomic divide in the scholastic performance and proficiency among students in rural, suburban, and metropolitan areas.

These analysts identified that wealthy household children were more inclined to flourish and thrive in scholastic institutions. Households that could afford greater expenditures diversified texts, computers, private school tuitions, and private ancillary instruction, increased opportunities for their child's scholastic progress. Furthermore, they argued that households with one or both parents with college degrees possessed greater cultural capital, which further prompted their offspring to increased outstanding scholastic achievements. Some analysts, however, were more inclined to assert that better genes inherited from parents were more likely to result in efficacious students with higher scholastic performances and proficiencies. Furthermore, the mindsets, demeanors, and cultures within certain households more closely mimicking scholastic institutions assisted students from those households in attaining scholastic proficiency and higher academic achievements; in short, the household environment itself could help students learn more if it were closely attuned to that of schools. Undoubtedly, various households would be in the habit of utilizing erudite terminology, and this too, would positively impact any offspring's scholastic achievements, providing them with a distinct advantage when attending scholastic institutions..

The potential collapse of the state education system

In a sense, it might be thought that the education of Japan faces a critical moment with various aspects. The recent education "reform" is part of the LDP government's efforts to promote patriotism and remilitarize the country in preparation for aggression abroad (Okada 2017).

Recent reforms to Japan's academic system based on the principle of equality, specifically 
the equality of education opportunity, would eventually induce a divergence from mandatory education. Alternatively, LDP education reforms advocate and endorse market principles, selections and rivalries, and school rankings. Prime Minister Abe encourages the neo-liberal and the neoconservative policy of synchronicity and harmony of liberalization and centralization as one. Market force founded liberalization or individualization is essentially a channel for engendering and promoting variety and distinction or contrast among scholastic institutions, while successive LDP government centralization efforts safeguard its right (wing) oriented liberalization.

Repercussions of presently prevailing LDP education reform has already been deliberated in diverse areas, yet many still condemn the reform generated economic imbalances and the amplification of inequality of opportunity it has induced in divergent classes. Education Sociologists (Fujita, 2010) noted that the 'school products market' established by the school select system is distinct from general commodity markets specifically due to its 'zero-sum-game basis' element. This characteristic states that households obtain comparatively high educations, other households receive comparably low educations. In other words, the 'school products market' introduces and propagates broader scholastic divides by promoting distinctions between scholastic institution hierarchies and household environments. This results in concern over involving all children, parents, teachers, and schools in a fierce competition, and separating them into "winners" and "losers" respectively, which actually contradicts the notion of "self-responsibility" and merely assumes equality of education results.

It can be said that even though the Japanese Constitution (Article 26) and the Fundamental Law of Education (Article 3) specify that "the people shall all be given equal opportunities of receiving education according to their ability." The successive LDP governments have violated this principle with conservatives ignoring the "equal" part and progressives the "ability" part. Without a revision of the COS that addresses the incentive and curriculum issues applicable to students from disadvantaged social backgrounds, social stratification will become an even more serious problem, as will those of motivation and dropout.

\section{Conclusion}

This article attempts to discuss the possibility and difficulty of the contemporary issues of revising the COS, which affects the traits of learning in Japan's compulsory education as the revision of the COS always leads to the policy changes of children's learning methods in school. Then this article discusses current issues, how the study of education could approach these issues, and the means to indicate a focused method on the perspectives of equal opportunity.

The crucial plan over the last three decades has centered on the type of 'ability' and 'skill' compulsory education should target for children to acquire. The Japanese government asserted that in a knowledge based society, the mere memorization of data and method is no longer sufficient to guarantee success. Children require more conceptual insight and perception of convoluted multiplex rhizomatic concepts. Since, as the government maintains, learning is central to the knowledge society, children need to develop the capacity to competently implement and manage concepts with inventive imagination in order to engender further concepts, original products, fresh theories, unique intelligence, and cutting-edge expertise. Currently, there is pressure to manifest this development through a revision of the COS concentrating on children's education instead of revising configurations and the didactic management even though no categorically explicit elucidation of what that might mean exists yet. For example, what does active learning genuinely denote or represent in specific objective language? Why is active learning important? Is there a fundamental expertise in and firm grasp of knowledge acquisition sufficient for policy-makers to direct the course of pedagogical and didactic change?

There has been a shift from a relatively democratic education system to a centralized system, in which founding, teaching, and curriculum are centrally controlled, and the subjection of schools to market forces has increased social and academic divisions. Questions about the nature and element of children's 'ability' in school learning have been repeatedly debated during post-war periods by the governments, education authorities, teachers, and parents.

Various education sociologists in Japan characterize the LDP's type of education system reform as lacking logic, dialectic coherence, and basic appropriateness. They further find it regulates, dominates, and manipulates capacities of institutional education and the neighboring communal_society. Moreover, they continue to criticize the LDP's education system reform due to the significant risk it holds of inducing an even greater inequality of educational opportunity. 
The rarity of educational opportunity in Japan is more evident in the limitation of access to high-quality primary and secondary education to children whose households are affluent enough to afford accommodation in at least middle-class neighborhoods, or to those who can afford private schools. Since education is an important role of any government, and because the government is the predominant provider of this opportunity to the masses, appropriately distinct restrictions on its dissemination and delivery must and do exist.

\section{References}

Cave, P. (2007). Primary School in Japan, London: Routledge.

Chiavacci, D. \& Hommerich, C. (eds). Social inequality in post-growth Japan : transformation during economic and demographic stagnation, $\square$ Routledge Curzon contemporary Japan series $\square$

Cummings, W.K. (1982). "The egalitarian transformation of postwar Japanese education." Comparative Education Review, 26(1), 16-35

Fujita, H. (1997). Kyōiku kaikaku: Kyousei jidai no gakkou zukuri [Education reform: Building schools in an era of coexistence], Tokyo: Iwanami shoten.

(2010) '21 seiki no kyōikukadai to kyōiku kaikaku no yukue' (Education challenges and education reform of the 21 st century), in Fujita, H and Omomo, T.(eds) (2010) Ga'kkō kaikaku (School reform), Leadings. Japanese education and society Inequality of education" and social education of the leading Nippon 11, Tokyo, Sanseido, pp. 221-229.

Central Council for Education. (2008). Revisions on the Courses of study for kinder garden, primary schools, junior high schools, high schools, and schools for special needs education. Available at: http://www.mext.go.jp/a_menu/shotou/new-cs/information/1290361.htm [Accessed 30 January 2019] (In Japanese).

DeCoker, G. \& Bjork, V. (Eds) (2013). Japanese education in an era of globalization: culture, politics, and equity. New York : Teachers College Press.

Kariya, T. (2001) Kaisō nihon to kyōiku kiki (Hierarchal Japanand education crisis - inequal reproduction and motivated unequal society), Tokyo, Yushindōkōbunsha.

Kawaguchi, D (2013), "Fewer School Days, More Inequality”, Hitotsubashi University Global COE Hi-Stat Discussion Paper Series 271, Hitotsubashi University.

Mack, O., Khare, A., Kraemer, A., \& Burgart, T. (2015). Managing in a VUCA World. Springer.

MEXT. (Ministry of Education, Culture, Sports, Science and Technology JAPAN) (2013a). Current status of Community School registration, Available at: http://www.mext.go.jp/a_menu/shotou/community/school/detail/1335832.htm .[Accessed 12 September 2018] (In Japanese).

........(2013b) Towards more resilient education (comments by Ministry of Education), Available at:

http://www.mext.go.jp/b_menu/houdou/28/05/1370648.htm. [Accessed 11 September 2018] (In Japanese).

Mimizuka, H. (2008). "Chosa kenkyu no gaiyo" [Overview of the research study] in Kyōiku kakusa no hassei, kaisho ni kansuru chōsa kenkyū hokokusho [Research report on the generation and resolution of educational inequality]. Benesse Educational Research and Development Institute.

Okada, A (2011) Education Policy and Equal Opportunity in Japan (Asia-Pacific Studies: Past and Present), New York: Berghahn Books

-(2017) "Political discourse and education reforms concerning "equality of educational opportunity", in Chiavacci, D. \& Hommerich, C. (eds). Social inequality in post-growth Japan : transformation during economic and demographic stagnation, $\square$ Routledge Curzon contemporary Japan series $\square$ 166-175.

Petrie, N. (2014). Future trends in leadership development. Colorado Springs, CO: Center for Creative Leadership.

Powell, W., \& Snellman, K. (2004). "The knowledge economy," Annual Review of Sociology, 30, 199-220.

Stehr, N. (1994). Knowledge Societies. London: Sage Publications.

UNESCO. (2005). Towards knowledge societies (UNESCO World Report). Paris: Author. 